\title{
Contractual Systems in the Oil and Gas Sector: Current Status and Development
}

\author{
Fatima Dirani * and Tatiana Ponomarenko
}

check for

updates

Citation: Dirani, F.; Ponomarenko, T. Contractual Systems in the Oil and Gas Sector: Current Status and Development. Energies 2021, 14, 5497. https://doi.org/10.3390/en14175497

Academic Editor: Sergey Zhironkin

Received: 21 July 2021

Accepted: 30 August 2021

Published: 3 September 2021

Publisher's Note: MDPI stays neutral with regard to jurisdictional claims in published maps and institutional affiliations.

Copyright: (c) 2021 by the authors. Licensee MDPI, Basel, Switzerland. This article is an open access article distributed under the terms and conditions of the Creative Commons Attribution (CC BY) license (https:// creativecommons.org/licenses/by/ $4.0 /)$.
Faculty of Economics, Saint-Petersburg Mining University, 21st Line V. O., 2, 199106 Saint Petersburg, Russia; ponomarenko_tv@pers.spmi.ru

* Correspondence: s205101@stud.spmi.ru or fatimadirani8@gmail.com

\begin{abstract}
Production activities in the oil and gas industry are capital-intensive and associated with high technology, with these assets not always being available to oil-producing countries or national companies. Any form of interaction between the parties involved in natural resource extraction requires clear regulation regarding contractual relationships. This study attempts to analyze Indonesia's production sharing contract system in order to assess its applicability to other conditions. The article covers the key aspects of contract theory, provides a classification of contractual systems in the oil and gas sector, and discusses the most common types of contractual agreements. It also considers the key principles of production sharing contracts (PSCs), analyzes the development of PSC practices in Indonesia over the past sixty years, and highlights PSC advantages and disadvantages.
\end{abstract}

Keywords: production sharing contract (PSC); production sharing agreement (PSA); concession; Indonesia; oil and gas sector; contracts

\section{Introduction}

As a rule, in developing countries with significant hydrocarbon reserves, neither the state nor private companies have enough experience and/or capital to develop their natural resources. Therefore, they start looking for ways to attract foreign capital or cooperate with foreign companies in various forms. The key issues for oil companies and the state regarding such agreements are the distribution of income and risks shared between the parties.

The low level of technological development and lack of experience in the oil and gas sector in developing countries results from the following factors, which were identified by analyzing the situation in Lebanon.

\subsection{Lack of a Pool of Scientists and Researchers in Specific Areas}

For example, Lebanese universities (Beirut Arab University and Lebanese American University) started to offer petroleum engineering programs only in 2013 [1]. The prospects for the development of the oil and gas sector emerged in 2011, and petroleum engineering is still considered one of the rarest specialties in Lebanon so there are very few Lebanese educators in this area.

\subsection{Brain Drain}

Lebanon has a highly qualified and skilled population. However, more and more professionals leave Lebanon each month due to the unprecedented economic crisis. Some 72,000 engineers and architects are registered in Lebanon, half of whom work outside the country [2]. The World Bank issued a report indicating "a dangerous depletion of resources, including human capital" and stating that emigration was becoming an "increasingly desperate option" for many professionals [3]. 


\subsection{Institutional Environment}

A four-year delay of Lebanon's first oil and gas exploration and production (E\&P) licensing round slowed down the development of the industry [4]. The bidding round only resumed in 2017. The inadequate institutional environment has reduced the competitiveness of the oil and gas industry, while other nations, notably Israel, Cyprus, and Egypt, made major discoveries in the deep waters of the Eastern Mediterranean.

\subsection{Inability to Make Public Investments in Relevant Research and Infrastructure}

The quality of Lebanon's infrastructure is one of the lowest in the world, being ranked 130th out of 137 countries [5]. The country's debt, as well as the lack of official budgets from 2005 to 2016, led to a sharp reduction in public spending on infrastructure, which poses risks for private businesses. Electricity availability has been one of Lebanon's major problems since the civil war and is ranked as the second biggest obstacle to investments in Lebanon [6]. Inefficiency and corruption in this sector are among the largest burdens on the public budget. In 2013, electricity subsidies reached $\$ 2.20$ billion, or almost $15 \%$ of the government budget [7]. Many new technologies are generally capital-intensive, and the state cannot allocate sufficient funds for the independent development of the oil and gas sector. According to the Lebanese Ministry of Finance, the debt-to-GDP ratio in Lebanon is estimated at $163.7 \%$ [8].

Based on the above, we can conclude that the state cannot ensure the development of the oil and gas sector, and private businesses do not show any initiative. All of the above makes it necessary to study mixed forms of cooperation between the state and business at the initial stage of the development of oil and gas projects. Such forms can differ and include contractual and concessionary systems.

The experience of using various types of contractual systems in the oil and gas sector has been analyzed using case studies of Algeria, Angola, Australia, Nigeria, Norway, Great Britain, China, Argentina, Malaysia, and the USA.

The main aspects of the contractual agreement theory have been sufficiently studied, but the factors influencing the choice of the PSC model have not been identified.

The purpose of the study is to assess the existing contractual systems used in the oil and gas sector in developing countries (Indonesia) and the main expected changes that should be considered in these countries.

Research objectives:

(1) Identify the factors of formation and change of the contractual system using the example of PSCs in Indonesia for the period from 1960 to 2020.

(2) Analyze PSC application problems, advantages, and disadvantages.

(3) Identify potential directions in the development of PSC systems, taking into account modern challenges.

(4) Justify the specifics of PSC contracts and the implementation of the win-win principle for the oil and gas sector of Lebanon.

\section{Materials and Methods}

(1) Through a PESTEL analysis, we studied the conditions for the creation of the oil and gas sector in Lebanon.

(2) Through a literature review and an analysis of Indonesia's experience in using PSCs since 1966, we identified PSC characteristics that differentiate them from other contractual systems.

(3) We identified the factors of changes in Indonesia's contract system that evolved through five generations of contracts from 1966 up to now.

(4) We studied the factors that determine the essence of PSCs as well as their advantages and disadvantages.

(5) We analyzed the main issues and directions in PSC development in Indonesia that can be used as a foundation for contractual systems in other developing countries with the aim of developing their oil and gas sectors. 
(6) Based on the analysis of the contract theory statements, the requirements for PSA contracts for the development of offshore oil fields in Lebanon were clarified.

(7) The implementation of the principle of win-win game theory is proposed when the interests of the international oil company and the state are coordinated for the subsequent development of PSA parameters for the development of offshore oil fields in Lebanon.

\section{Literature Review}

The goal of public regulation of oil and gas production is to make sure that hydrocarbon resources are rationally used, which allows for obtaining the maximum macroeconomic effect while maintaining environmental and social stability [9]. Therefore, when choosing a method of public regulation, various political, economic, technological, social, environmental, and legal factors must be taken into account. These factors are covered within the PESTEL analysis framework. Table 1 presents the results of a PESTEL analysis of the Lebanese oil and gas sector.

Table 1. The results of a PESTEL analysis of the Lebanese oil and gas sector.

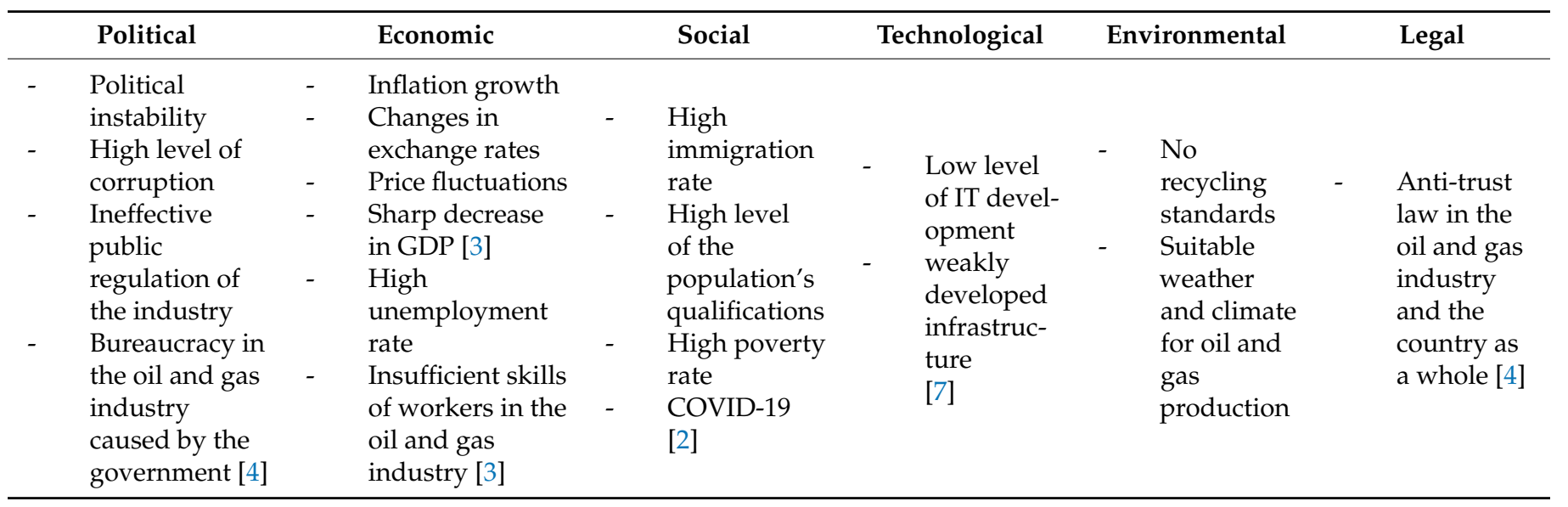

Compiled by the authors based on The World Bank 2021, LOGI 2014, UPI 2020, Islamic Development Bank 2018.

The cumulative influence of these factors along with the uncertainty and specific risks determine the choice of the collaboration model.

The contractual model is based on the contractual principle, distinguished by detailed regulation of the operator's activities, and applied to geologically, technologically, and economically complex oil and gas fields. By writing into the contract the events that may occur, it is possible to reduce the uncertainty in economic relations between the owner of the resources and the operator [10].

The concessionary model can be characterized as the joint participation of the owner (state) and the partner company in the exploitation of natural resources. The fundamental difference of this model lies in the partial assignment of the state's rights to private capital. This model gives maximum possible economic freedom to oil and gas companies. The concessionary model is used to different extents in more than a hundred countries around the world, especially in the development of North Sea oil and gas resources. The contracts were concluded between oil companies and the governments of the UK and Norway [11].

Contract analysis is based on institutional theory, focusing on structures for managing contractual relations or governance structures that support coordination in the face of uncertainty in the external environment and contractual incompleteness. Depending on the situations associated with the need to ensure long-term coordination of the actions of economic agents, there are classical, neoclassical, and relational contracts [12].

Contract theory was developed in studies by R. Coase [13], O. Williamson [14], M. Jensen [15], I.R. Macneill [16], J.R. Commons [17], V.L. Tambovtsev [18], I.B. Sergeev [11], N.V. Vasilenko [19], A.A. Auzan [20], and many other researchers. 
Contract theory is based on two imperatives that make it possible to develop this theory and apply means of formalizing its provisions:

(1) The contract is a process of interaction between two parties with different sets of rights and opportunities. The principal hires the agent who creates some benefit but whose actions cannot be constantly monitored. The agent can act in such a way as to gain benefits for himself and not for the principal.

(2) The contract is a process that goes through three stages. The first is the choice of an agent by the principal, the second is the conclusion of a contract, and the third is the fulfillment of the contract, during which revisions of its terms are allowed.

The most important point of contract theory is that, in contrast to the standard assumption of economic theory, in which everyone pursues their own interests, the goals of the principal and the agent are similar or agree with each other. If both sides wanted the same thing, the principal could give the agent complete leeway. But in practice, this is not the case: in the most simplified form, the principal wants to pay as little as possible, and the agent wants to work as little as possible.

Usually, in contract theory, the "principal-agent" relationship is viewed from the perspective of the principal, who needs to make sure that the agent acts in the right way [21]. Since the 1980s, more than 120 countries have introduced concession agreements. They are widely used in France, Italy, Germany, and dozens of other countries following a civil law system. In countries with specific legislation governing the development of the oil industry, exploration concessions may be referred to as licenses. This practice exists in Norway, UK, USA, Australia, and other countries with developed market economies and property rights protection [22].

Contract theory tools are developed using game theory. In the work by John Nash on non-zero-sum games, a mathematical model was used to prove that all participants in the contractual interaction either win or lose. This revolutionary conclusion was developed by S. Covey, who described in detail the win-win principle [23]. In general, win-win contracts are used to describe approaches to everyday life, politics, business, and science, in which stakeholders have certain overlapping interests and all stakeholders can win [24-27].

These contracts are generally defined as "a set of principles, practices and tools that enable a range of interdependent stakeholders to develop a win-win set of shared commitments". Interdependent stakeholders can be people or organizations. Mutual satisfaction generally means that the parties do not get everything they want but can be reasonably assured that they will get whatever it was to which they agreed. Shared commitments are not just good intentions but carefully defined conditions. If there is a contingent liability, it must be made clear to ensure that all stakeholders understand it as part of the agreement.

The main goal of win-win collaboration is to agree on a set of mutually satisfactory agreements that will be the basis of requirements, constraints, and plans for the project [28]. Participants in win-win collaboration are distinguished by the desire to learn information about their partner's goals, focusing on acquiring common benefits and strengthening long-term relationships $[29,30]$. A mutually beneficial relationship aims to improve quality, improve quality, create value, achieve greater efficiencies, and secure resources, with the ultimate goal being to create sustainable competitive advantages [31-33]. The stakeholders achieve win-win when the agreements cover all of the win conditions and there are no unsettled issues.

The win-win negotiation model has four main tools: Win condition: capturing the desired objectives and constraints of the stakeholder; issue: capturing the conflict between win conditions and their associated risks and uncertainties; option: capturing a decision choice for resolving an issue; agreement: capturing the agreed upon set of win conditions which satisfy stakeholder win conditions and/or capturing the agreed options for resolving issues [28].

Many researchers from different countries (the USA, China, Russia, the UK, and Nigeria) have been studying PSCs. Johnston (1994) discussed and studied in detail the contract 
elements of PSCs in International Petroleum Fiscal Systems and Production Sharing Contracts [34]. Wu and Wang (2006) studied PSC risks [35]. Mudford and Stegemeier (2003) examined the sensitivity of production sharing contract terms under both technical and price uncertainties; they also compared different PSCs in three countries, namely Egypt, Angola, and Equatorial Guinea [36]. Bindemann (1999) investigated the economics of PSCs at a fixed oil price and the impacts of contract elements on PSC economic indices, NPV, and IRR [37]. A.G. Vasilyeva (2009) analyzed international experience in the implementation of production sharing agreements for the operation and development of oil and gas fields [38]. Taiwo Adebola Ogunleye (2015) studied the concept and key characteristics of PSCs [39]. He analyzed PSC mechanisms in Nigeria, highlighted different PSC models implemented in Nigeria, and found significant differences between them.

PSC is a tool to fulfill contractual liabilities between the host country and the foreign oil country (FOC). FOCs play the role of the agent who should have the structure that can balance the HC indisputable right to control the oil companies' behavior [40] and the company's freedom to follow whatever actions that are suitable [41].

As a result of intensive long-term research, two types of petroleum fiscal systems were created, which are the concession system and contractual system [34].

Under concessionary systems, the agreement between the host government and companies is concluded in the form of a license agreement. The classical concession is characterized by four features: the development rights covering vast areas and sometimes even an entire country is granted to foreign companies; contracts are signed for long periods; the foreign contractor has complete control over the schedule and manner in which natural resources are developed; the host government has hardly any rights apart from the right to receive a payment based on production [37]. In modern concessionary systems, the contractor is still granted an exclusive right to explore, develop, and export petroleum, but the contract period becomes shorter. The contractor has to comply with obligations and pay higher royalties and bonuses.

Based on the ownership of resource rights, concessionary systems are divided into two types: American, where resource rights belong to the individual who possesses the land where hydrocarbon reserves are located, and non-American type, where resource rights belong to the respective government.

In contractual systems, there are two main types: service contracts and production sharing contracts/agreements.

A service contract means that a company concludes an agreement to perform E\&P operations, while the host government provides it with capital and technological knowhow. The government has greater control over the exploration and exploitation of its resources. Thus, the company does not have a share in the revenue produced but receives a payment for providing services [42]. Service contracts are divided into risk service contracts and pure service contracts depending on who bears the exploration risks (the government in the former case and the company in the latter).

In production sharing contracts, the ownership of the natural resource rests with the state, but at the same time companies are able to manage the development of hydrocarbon fields [43]. The company bears all exploration risks and receives a share of oil revenue. Under a PSC in Indonesia, all E\&P costs will be covered if an oil and gas field prove to be commercially viable. In contrast, under a PSC in Peru, the company bears all E\&P risks, but it receives a greater share of oil revenue than in Indonesia.

According to Oon, issues of best practices in the industry and strong government oversight are the key ones in the case when oil industry can smartly manage the benefit of both the host country (HC) and the FOCs [44]. Bindenman (1999) introduced the best policies in the oil industry as she noted that the host government mainly focuses on the best practices that are applied by the FOC during the uncertain exploration and development stages to maximize total production [37].

In his turn, Briston (1984) also mentioned that developing countries need the industry's best practices, especially in accounting and auditing, that enable them to control 
multinational corporations and help them in economic planning and decision-making [45]. This should take into account non-financial aspects, including information related to the procurement of resources on site, repatriation of profits and capital, local capital participation, employment rates, local transportation system, environmental protection, and the construction of social facilities. These aspects were not studied by PSCs [46].

Production sharing contracts are applied in several countries: Qatar, Guatemala, China, Jordan, Bangladesh, Egypt, Malaysia, Angola, Syria, Jordan, Libya, Peru, and Indonesia [47].

Concession agreements are widely used in Kuwait, Sudan, Angola, Ecuador, Australia, Canada, Norway, the UK, the USA, Thailand, and some Middle Eastern countries [48].

Service contracts have been developed in many countries like Venezuela, Kuwait, Iraq, Bolivia, Ecuador, Turkmenistan, Iran, and Mexico [49].

\section{Key Research Findings and Discussions}

In countries using PSCs, legal regulations for their application have been developed. A production sharing contract (PSC) is defined as a contract that is signed between the government and one or more investors concerning how much percentage of resource extracted from the country each will receive after the investors have recovered a specified amount of costs and expenses [37].

The principal goal of PSC is to attract multinational oil companies that are ready to transfer and share their technological expertise and money to extract reserves in the HC [50].

\subsection{Parties and Instruments}

A production sharing contract formally defines the rights and obligations of the parties: an international oil company (IOC) and a government representative, such as the head of the state, the ministry, or the national oil company (NOC). PSCs have common key characteristics despite the differences in their structure.

(a) IOC is selected by the host country and a contract is signed for a certain time and region;

(b) IOC's operations can be done under the HC's supervision;

(c) IOC shall give all the materials, equipment, and personnel required to conduct development and production processes;

(d) IOC has the right to recover the investments in the production;

(e) after the costs have been defrayed, the remaining from the extracted resources are shared between both parties in proportions given by PSC;

(f) IOC's revenues are subject to tax [51].

\subsection{Production Ownership}

In PSCs, the producing countries assign only the exclusive right to perform E\&P operations, yet the produced oil and gas are the government's property [52]. If the IOC's discovery is commercially viable, the producing country as the owner of the reserves must refund exploitation costs ("cost oil") and share the remaining oil ("profit oil") between the state (or the NOC) and the IOC in proportions previously agreed in the contract.

\subsection{Facility Ownership}

According to PSCs, after the contract term is ended, the infrastructure is assigned to the host country without any added charges. In addition, all information obtained under a license or as a result of E\&P activities will be the state's property [53].

\subsection{Responsibilities of IOCs and the Government}

The host government can work directly or by its agencies and departments. NOC can act as the organ that is responsible for granting E\&P rights to the investor. IOCs can control exploitation and production operations on their own or have a smaller role. In general, 
the entire responsibility of the management is held by the host country and the routine operations are in the hand of the international oil company.

Having experienced more than 50 years of development, the PSC system in Indonesia is the most vivid example of PSC application in the world. Therefore, its evolution is further analyzed, and the factors of change are identified [54].

A production sharing contract was first applied in Indonesia [55]. The first contract was signed in 1966 by the International Indonesian American Petroleum Company (IIAPCO). The Indonesia's PSCs has the following peculiarities.

(1) Management is entrusted in the national oil company. Contractors, especially foreign oil companies, are the operators who are responsible to NOC for operations by the agreed work programs and the budget.

(2) All financial and technical supports for petroleum operations are provided by the contactor who also affords the risks associated with operating costs.

(3) Each year the contractor must prepare a work program and an operating budget to be approved with NOC.

(4) All equipment purchased by the contractor becomes the property of NOC upon arrival in Indonesia.

(5) NOC has the right to all data gained from the operations.

(6) The contractor pays Indonesian taxes on income. NOC refunds the contractor for other taxes paid for the work.

(7) The contractor must supply Indonesia's domestic demand for crude oil.

There are three characteristics of Indonesia's PSC system. First, one company manages one work site. Second, the company is responsible for all risks associated with exploration, the government owns both the resources and the facility, and the company has the right to produce oil and gas. Third, all production costs are defrayed by the government. Therefore, any E\&P operation or budget that is planned shall have government approval. These characteristics demonstrate the state's sovereignty over natural resources.

By analyzing the contractual system in Indonesia, we identified five generations of contracts and the factors influencing their changes. Barrow (1993) discussed Indonesia's PSCs developed through three generations: 1966-1976 (1st generation), 1976-1987 (2nd generation), 1988-1994 (3rd generation). In our opinion, the 1994-2008 and 2008-2017 periods (4th and 5th generation, respectively) should also be distinguished. The new contract will be signed in 2022. Table 2 analyzes and systematizes the key characteristics of PSC contracts and identifies transition factors as well as innovations in new generations.

Table 2. Key generation characteristics of PSC contracts in the oil and gas sector (a case study of Indonesia).

\begin{tabular}{|c|c|c|}
\hline Generations & Features & Generation Transition Factors \\
\hline $\begin{array}{c}\text { 1st generation } \\
(1966-1976)\end{array}$ & $\begin{array}{l}\text { - The contractor's equipment was transferred to the } \\
\text { national company. } \\
\text { - Contractors with more than one work site in Indonesia } \\
\text { were unable to consolidate financial results to calculate } \\
\text { their obligations to the government. } \\
\text { - Cost recovery was } 40 \% \text { of the production }[55,56] \text {. } \\
\text { - } \quad \text { Contactors must supply the domestic market. } \\
\text { - After-tax split for oil: government }(85 \%) \text {, contractor } \\
\text { (15\%), } 65 / 35 \text { for border territories } \\
\text { - After-tax split for gas: } 70 / 30 \\
\text { - Effective tax rate: } 56 \text { (the general combined corporate } \\
\text { and dividend (C\&D) tax rate) [57]. }\end{array}$ & $\begin{array}{l}\text { - The PSC system was amended in early } \\
1974 \text { owing to the rapid growth in oil } \\
\text { prices in } 1973 \text {. } \\
\text { In 1975, a USA tax ruling disallowed tax } \\
\text { credits for corporate taxes paid in } \\
\text { Indonesia by the contractors under PSCs. }\end{array}$ \\
\hline
\end{tabular}


Table 2. Cont.

\begin{tabular}{|c|c|c|}
\hline Generations & Features & Generation Transition Factors \\
\hline $\begin{array}{l}\text { 2nd generation } \\
\text { (1976-1988) }\end{array}$ & $\begin{array}{l}\text { - } 100 \% \text { cost recovery (costs were calculated based on the } \\
\text { accepted accounting principles with no upper cap of } 40 \%) \\
\text { - } \\
\text { After-tax split for oil: government }(85 \%) \text {, contractor } \\
(15 \%), 65 / 35 \text { for border territories }\end{array}$ & $\begin{array}{l}\text { - The fluctuation of oil prices especially in } \\
\text { the 1980s created difficulties. } \\
\text { - The National Oil Company has } \\
\text { introduced a new rule: "Declaration of } \\
\text { commercialization", in which a new field } \\
\text { could be declared commercial for } \\
\text { development only if the government } \\
\text { accounted for at least } 49 \% \text { of the } \\
\text { cash flow. }\end{array}$ \\
\hline
\end{tabular}

- $\quad$ The government provided some incentives to boost oil exploration activities.

- Government revenue for small hydrocarbon fields was reduced to $80 \%$ in traditional areas and to $75 \%$ in border territories.

$\begin{array}{ccl}\text { 3rd generation } & \text { - } & \text { After-tax split for gas did not change. } \\ (1988-1994) & \text { - } & \text { The Domestic Market Obligation (DMO) fee grew, }\end{array}$

(1988-1994) - $\quad$ reaching first $10 \%$ of the export price and then $15 \%$ in 1992.

- $\quad$ The combined tax rate was reduced from 56 to 48 .

- $\quad$ The concept of First Tranche Petroleum (FTP) was introduced in 1988.

\begin{tabular}{clll}
\hline & - & The government introduced 65/35 after-tax split for oil. & - \\
4th generation & - & Combined tax rate: 44 \\
$(1994-2008)$ & - & After-tax split for gas: 60/40 & remote areas (eastern provinces) \\
& - & After-tax split became negotiable \\
& - & Cost recovery items became limited \\
5th generation & - & Incentives in other areas, such as investment credits \\
$(2008-2017)$ & - & Combined tax rate: 40
\end{tabular}

- A sharing concept based on gross production without regard to a cost recovery mechanism.

- Retention of the following key principles:
(a) the ownership of natural resources remains with the government up to the point of delivery;
(b) control over the management of operations lies ultimately with the government;
(c) all capital and risks are borne by contractors.

2017-present

- $\quad$ The basic split rates should form the basis for determining the split rates at the time of development plan approval.

(a) for oil: $57 \%$ (government); $43 \%$ (contractor)
(b) for gas: $52 \%$ (government); $48 \%$ (contractor) [57]

Compiled by the authors based on Barrows 1993, Sihotang 2003, and PWC 2019.

Key differences between earlier and later generations are as follows:

(a) Rather than having a fixed after-tax share, PSCs became more flexible with respect to the proposed production sharing percentage;

(b) PSCs now prescribe a DMO for natural gas;

(c) the government and the contractor are both entitled to $20 \%$ FTP of oil production;

(d) the profits tax rate for the contractor is $20 \%$;

(e) some costs (e.g., those associated with seismic surveys) may be defrayed;

(f) the government must approve any changes to the direct or indirect control of the PSC system [57].

Changes to the PSC system during the first three generations tended to bring more benefits to contractors rather than to the government. In particular, the share of the state tended to decline in 1981 despite the growth in global oil prices, while the contractor's share tended to increase. 
A number of incentive packages for exploration were made by the government in the early 1990s to get additional investment in the oil production sector, which increased the share of contractors by reducing the share of the state [58].

The introduction of a new cost recovery scheme in 1977 to replace the $40 \%$ cap on cost recovery appears to have resulted in the loss of the government's share [56]. One issue is that this new scheme has many weak points that can be used by contractors to inflate their costs, which makes the industry highly inefficient. Furthermore, changes in the content of PSCs do not seem to have added value to the oil industry since the current structure of managing the oil industry-with the NOC (now BP) as the manager the IOC only as the contractors to the NOC (now BP) - does not have enough capabilities and competence for effective control. In this respect, one could argue that, in order for the changes in the content of PSCs between the host country and IOCs to add value to the industry, the current accountability relationship between them needs to be properly restructured [40].

The analysis of PSC development/evolution showed that the Indonesian oil and gas sector has different PSC models with different incentives, such as investment credits, reduction in the contractor tax rate, and reduction in the state's production share.

This experience can be used in other oil and gas producing countries, for example, in Lebanon, where in the event of a dispute over maritime borders similar incentives can be offered to encourage investment.

In general, international oil companies prefer to sign production sharing contracts in countries with low institutional maturity because they feel more secure given the risks of political instability, lack of transparency, and legal uncertainty in the host country. Examples are such emerging economies as Angola, Indonesia, Lebanon, and others.

The exogenous factors that influence the choice of the model can be divided into three groups:

(a) time frames (terms of construction and oil field development; oil well lifespans; the total term of project implementation);

(b) technological features (well productivity; production performance; production peaks);

(c) economic parameters (oil transportation costs; the number of workers employed in well servicing; administrative staff) [59].

Many factors can influence the PSC content. Among them are political factors, the fiscal policy of the host country, the influence of brokers and decision-makers, the need for stabilization, corruption, the level of development of the regulatory framework, and production capacity.

In modern conditions, environmental, social, and governance (ESG) factors are becoming important in the development of mineral and oil and gas resources, and they should be taken into account when defining the parameters of agreements as it creates value for society.

Production sharing contract advantages:

(a) practices are more workable than purely fiscal ones, which allow conditions to be changed or negotiated (for new contracts) in accordance with the business potential of a particular work site, market circumstances, etc.;

(b) after signing, they have the strength of the agreement and, unlike tax legislation, cannot be modified unilaterally by the government [60];

(c) they enable the state to supervise the contractor's obligations;

(d) low risks for the host country, as the IOC bears all operational and financial costs and risks;

(e) transfer of knowledge from the IOC to the host country, increasing the employment rate and improving the quality of training in the country;

(f) the government exercises sovereign control over the nation's natural resources;

(g) the government obtains a share in the production and the financial benefits associated with these wealth-producing assets without having to make an investment unless it agreed to do so [61]. 


\section{Disadvantages:}

(a) The PSC system is considered to be difficult for the government to inspect and control because it is generally difficult to calculate cost oil and profit oil. Thus, the profit calculation process is hard to do [62].

(b) This type of oil and gas agreement is very complex in structure and requires negotiations at a high level. The owner must have access to financial, commercial, legal, environmental, and technical expertise as well as information.

(c) Under the terms of the PSC, the host-country government is generally a decisionmaker in oil field development. At the same time, it also gives oil companies a say in the enforcement of environmental and other standards when such standards are incorporated as contractual provisions [63].

Table 3 presents the main problems and directions in the development of the PSC system in Indonesia.

Table 3. Analysis of problems and possible solutions for the development of the PSC system in Indonesia.

\begin{tabular}{|c|c|c|}
\hline Problems & & Solutions \\
\hline $\begin{array}{l}\text { According to FTP conditions, } 20 \% \text { of } \\
\text { production is given to the government } \\
\text { before operating costs are reimbursed. } \\
\text { This type and level of effective royalties } \\
\text { impose high fees (taxes) on large oil basins } \\
\text { and can inhibit investment, especially at oil } \\
\text { prices [64]. }\end{array}$ & - & $\begin{array}{l}\text { The portion of FTP oil received by the } \\
\text { government should be reduced. } \\
\text { FTP tax should be paid gradually after } \\
\text { deducting the balance of accumulated } \\
\text { unrecovered costs. }\end{array}$ \\
\hline $\begin{array}{l}\text { Low price paid to contractors for fulfilling } \\
\text { obligations to supply oil to the domestic } \\
\text { market [64]. }\end{array}$ & - & $\begin{array}{l}\text { Contractors must be paid the international } \\
\text { price for any supply to the local market. } \\
\text { Indonesia's national refineries and marketing } \\
\text { industry should be liberalized. } \\
\text { Subsidizing the oil supply price on the } \\
\text { domestic market should be abolished. }\end{array}$ \\
\hline
\end{tabular}

The investment credit is applied at completely different rates to oil and gas production in accordance with the contract standard for tertiary and pre-tertiary reservoirs. However, it is not applied for the Frontier PSC [64].

The increase in the government's share of oil/gas profits is associated with a complex set of field profitability indicators [64].
Contractors should be provided with a large share of production in order to offset additional investment risks and costs. Compiled by the authors based on Energy and Mining Sector Unit East Asia and Pacific Region 2000.

As a result of implementing the proposed solutions, the following results will be obtained:

(a) elimination of economic obstacles to the development of marginal deposits, which will subsequently lead to an improvement in their economic situation and facilitate the attraction of PSC contractors to invest in hydrocarbon fields located in border territories, deep waters, or other areas associated with high costs and risks [65-69].

(b) elimination of obstacles to the development of oil and gas projects [70,71].

(c) combining numerous existing types of contracts into one.

For the conditions of oil and gas fields in Lebanon, PSC contracts must take into account the following elements: 
First, the legal objects to develop hydrocarbons on the shelf can be individual blocks or several blocks.

Second, the schedule and method of field development proposed by the contractor must be coordinated with the state authorities in order to ensure the most rational development of the block.

Third, the term of the contract should be determined based on the interests of the investor, profitability, and the timing of the block development; our analysis of the Indonesian experience showed that over 50 years there were five stages in the development of PSC. This means that external conditions are forcing government agencies to change the terms of the contract. This can be done only after its termination or the provision of flexible conditions in the contract itself, which should reduce the incompleteness of the contract.

Fourth, the rights of the state and government usually include taxes, the share of products, and the use of equipment and workers in the country where the oil is produced. In the case of Lebanon, the use of local resources and personnel can be difficult due to the lack of suitable resources or inadequate skills of the workers. Therefore, the contract may stipulate the conditions for training employees, selling technology, etc.

Implementing the win-win principle in the PSC and harmonizing the interests of the IOC and the state in Lebanon should be taken into account based on the previously discussed PSC issues:

- $\quad$ The choice of one or more blocks as a PSC object depends on the economic desires and investment opportunities of the IOC. At the same time, the joint development of two or more blocks by one contractor can bring additional (synergistic) effects both to the contractor himself and to the state, since CAPEX per unit of production, oil transportation costs, and others can be reduced.

- When determining the schedule and method for the block development, the interests of the state lie in the rational use of subsoil, compliance with the environmental and social interests of society and the maximum economic effect, and if the interests of the IOC are in the maximum commercial effect.

- $\quad$ The term of the contract and its terms, as noted, must be long in order to provide guarantees for both parties. On the other hand, a rapid change in the external environment, primarily the volatility of the oil price, should be taken into account in the contract, either on the basis of a change in the contractor/government shares, on the basis of a change in the DMO, or on the basis of a change in the tax rate.

- For the situation with Lebanon, the rights of the government may be expanded and additional conditions and requirements may be introduced, according to which the contractor must pay the costs of training workers, building infrastructure, or transferring technology to the state.

\section{Conclusions}

(1) The contract theory and the win-win principle underlie the definition of PSC parameters.

(2) Field development efficiency indicators are determined by many factors (goals of the state and companies, taxation and institutional schemes, geological and technical conditions, legal and political conditions, technological development, oil prices, the pandemic (COVID-19), environmental issues, and the country's infrastructure).

(3) The main factors of changes in Indonesia's contractual system were identified, among which are fluctuations in oil prices, changes in the accounting practices, identification of fields associated with high costs and containing small reserves, weakly developed institutional environment, and various risk factors.

(4) The key issues of the PSC system in Indonesia are the disadvantages associated with the terms of FTP, which reduces the contractor's profit from crude oil, the low price paid to contractors for fulfilling domestic supply obligations, different investment loan rates, and the increase in the government's share of oil/gas profits, which is associated with a complex set of field profitability indicators. 
(5) In modern conditions, ESG factors are becoming vital in the development of mineral, oil, and gas resources and should be included in the definition of the parameters of agreements.

(6) The following PSC practices can be used in other developing countries: reducing the portion of FTP oil received by the government; contractors should be paid the international price for any local market supply; contractors should be provided with a larger share of production to offset additional investment risks and costs; PSC conditions should be changed so that a direct connection is created between the share of the government's profit and the achieved profitability of the hydrocarbon field.

(7) We clarified the specifics of PSC contracts for the conditions of oil and gas fields in Lebanon, including objects of rights, such as blocks; rational development of the block when coordinating the schedule and method of field development; determination of the contract term based on the coordination of the investor's interests and the state, taking into account the profitability, the timing of the block development, the flexibility of the contract terms; inclusion in the contract of additional conditions for technology transfer, staff training, and others.

(8) In order to implement the win-win principle in PSC and harmonize the interests of the IOC and the state in Lebanon, one should take into account possible synergistic effects during the simultaneous development of several blocks; determination of the economic effect for the state and the commercial effect for the IOC, the values of which will suit both parties; flexible accounting in determining the terms and conditions of the contract of oil price volatility based on changes in the shares of the contractor/government, DMO, and tax rate; empowering the government in a contract with an innovation focus, whereby the contractor must pay the costs of training workers, building infrastructure, or transferring technology to the government.

Author Contributions: F.D. and T.P. jointly established the topic of the review and chose the classification approach; T.P. planned the methodology and supervised the paper; F.D. collected and analyzed the data; F.D. and T.P. jointly wrote the paper. Both authors have read and agreed to the published version of the manuscript.

Funding: This research received no external funding.

Institutional Review Board Statement: Not applicable.

Informed Consent Statement: Not applicable.

Data Availability Statement: Not applicable.

Conflicts of Interest: The authors declare no conflict of interest.

\section{References}

1. Elnashra. After the Oil Decrees Were Passed in Lebanon, What Is the Fate of Petroleum Engineering Students in Universities? Available online: https:/ / www.elnashra.com/news/show/1070991/ (accessed on 22 May 2021).

2. UPI. Lebanon's Brain Drain: Doctors, Nurses, Engineers Leaving Amid Crisis. Available online: https://www.upi.com/Top_Ne ws/World-News /2020/12/22/Lebanons-brain-drain-Doctors-nurses-engineers-leaving-amid-crisis/9091608581590/ (accessed on 22 May 2021).

3. The World Bank. Lebanon Sinking into One of the Most Severe Global Crises Episodes, Amidst Deliberate Inaction. Available online: https: / / www.worldbank.org/en/news/press-release/2021/05/01/lebanon-sinking-into-one-of-the-most-severe-glo bal-crises-episodes (accessed on 22 May 2021).

4. Lebanese Oil and Gas Initiative. Lebanon Postpones the Launching of Its Bidding Round, Again. 2014, pp. 1-2. Available online: https:/ /logi-lebanon.org/KeyIssue/Lebanon-postpones-launching-bidding-round (accessed on 29 May 2021).

5. Schwab, K. The Global Competitiveness Report 2017-2018; World Economic Forum: Cologny, Switzerland, 2017. Available online: http:/ / www3.weforum.org/docs/GCR2017-2018/05FullReport/TheGlobalCompetitivenessReport2017\%E2\%80\%932 018.pdf (accessed on 13 May 2021).

6. European Bank for Reconstruction and Development, European Investment Bank, and The World Bank. What's Holding Back the Private Sector in MENA? Lessons from the Enterprise Survey; License: Creative Commons Attribution CC BY 3.0 IGO; The World Bank: Washington, DC, USA, 2016. Available online: http:/ / www.enterprisesurveys.org/reports/MENA-report (accessed on 30 May 2021). 
7. Country Case Studies: Building Economic Resilience in Lebanon and Libya; Islamic Development Bank: Jeddah, Saudi Arabia, 2018. Available online: https://www.oecd.org/mena/competitiveness/ERTF-Jeddah-2018-Background-note-Case-studies-Lebano n-and-Libya.pdf (accessed on 22 May 2021).

8. Byblos Bank S.A.L. Lebanon This Week. Available online: https://www.byblosbank.com/Library/Assets/Gallery / Publications /LebanonThisWeek/Lebanon\%20This\%20Week\%20\%20682.pdf (accessed on 23 May 2021).

9. Varnavskij, V.G. Partnerstvo Gosudarstva i Chastnogo Sektora: Formy, Proekty, Riski; Nauka: Moscow, Russia, 2005 ; p. 315.

10. Kirsanova, N.Y.; Lenkovets, O.M.; Hafeez, M. Issue of accumulation and redistribution of oil and gas rental income in the context of exhaustible natural resources in Arctic Zone of Russian Federation. J. Mar. Sci. Eng. 2020, 12, 1006. [CrossRef]

11. Sergeev, I.B.; Ledovskih, V.A. Organizacionno-ekonomicheskie modeli nedropol'zovaniya. Zap. Gorn. Inst. 2008, 179, 20.

12. Tambovcev, V.L. Vvedenie v Ekonomicheskuyu Teoriyu Kontraktov; INFRA-M: Moscow, Russia, 2004; p. 144.

13. Coase, R.H. The New Institutional Economics. J. Inst. Theor. Econ. 1984, 88, 229-232.

14. Williamson, O.E. Revisiting Legal Realism: The Law, Economics, and Organization Perspective. Ind. Corp. Chang. 1996, 5, 383-420. [CrossRef]

15. Jensen, M.C.; Meckling, W. Theory of the Firm: Managerial Behavior, Agency Costs, and Ownership Structure. J. Financ. Econ. 1976, 3, 305-360. [CrossRef]

16. Macneil, I.R. Contracts: Adjustments of Long-Term Economic Relations under Classical, Neoclassical, and Relational Contract Law. Northwestern Univ. Law Rev. 1978, 72, 854-906.

17. Rutherford, M.H.J.R. Commons's Institutional Economics. J. Econ. Issues 1983, 17, 721-744. [CrossRef]

18. Tambovcev, V.L. Osnovy Institucional'nogo Proektirovaniya; INFRA-M: Moscow, Russia, 2009; p. 144.

19. Vasilenko, N.V. Razvitie neftegazovogo servisa kak organizacionnoj formy predprinimatel'stva v postindustrial'noj ekonomike. Zap. Gorn. Inst. 2017, 227, 597-602.

20. Auzana, A.A. Institucional'naya Ekonomika: Novaya Institucional'naya Ekonomicheskaya Teoriya; INFRA-M: Moscow, Russia, 2010; p. 416.

21. Voronov, Y.O. Teorii Kontraktov (o Nobelevskih Premiyah po Ekonomike). Mir Novoj Ekon. 2017. Available online: https: / / cyberleninka.ru/article/n/o-teorii-kontraktov-o-nobelevskih-premiyah-po-ekonomike (accessed on 14 June 2021).

22. Subbotin, M.A. Razdel Produkcii: Za i Protiv; Taktika: Moscow, Russia, 2007; pp. 187-196.

23. FB. V Chem Zaklyuchaetsya Princip “Vin-Vin” (Win-Win) i Kak Ego Ispol'zovat'. Available online: https:// fb.ru/article/431945 / v-chem-zaklyuchaetsya-printsip-vin-vin-win-win-i-kak-ego-ispolzovat (accessed on 1 June 2021).

24. Fisher, R.; Ury, W. Getting to Yes: Negotiating Agreement without Giving in; Penguin Books: New York, NY, USA, 1991.

25. Frankl, G. Enabling Winning-Scenarios for All in Knowledge Management, Monterrey. In Proceedings of the Positive Design Conference: Creating New Models of Possibility for All, Monterrey, Mexico, 3-5 April 2008.

26. Henderson, H. Building a Win-Win World: Life beyond Global Economic Warfare; Berrett-Koehler: San Francisco, CA, USA, 1996.

27. Rosenzweig, M.L. Win-Win Ecology: How the Earth's Species Can Survive in the Midst of Human Enterprise; Oxford University Press: New York, NY, USA, 2003.

28. Boehm, B.; Kitapci, H. The WinWin Approach: Using a Requirements Negotiation Tool for Rationale Capture and Use. In Rationale Management in Software Engineering; Springer: Berlin/Heidelberg, Germany, 2006; pp. 173-190.

29. Mintu-Wimsatt, A.; Graham, J.L. Testing a negotiation model on Canadian Anglophone and Mexican exporters. J. Acad. Mark. Sci. 2004, 32, 345-356. [CrossRef]

30. Zachariassen, F. Negotiation strategies in supply chain management. Int. J. Phys. Distrib. Logist. Manag. 2008, 38, 764-781. [CrossRef]

31. Dyer, J.H.; Singh, H. The relational view: Cooperative strategy and sources of interorganizational competitive advantage. Acad. Manag. Rev. 1998, 23, 660-679. [CrossRef]

32. Nyaga, G.N.; Whipple, J.M.; Lynch, D.F. Examining supply chain relationships: Do buyerand supplier perspectives on collaborative relationships differ? J. Oper. Manag. 2010, 28, 101-114. [CrossRef]

33. Rinehart, L.M.; Eckert, J.A.; Handfield, R.B.; Page, T.J.; Atkin, T. An assessment of supplier-customer relationships. J. Bus. Logist. 2004, 25, 25-62. [CrossRef]

34. Johnston, D. International Petroleum Fiscal Systems and Production Sharing Contracts; PennWell Books: Tulsa, Oklahoma, 1994.

35. Wu, H.Y.; Wang, A.D. Discussion of production-sharing contract risks. Inn. Mong. Petrochem. 2006, 7, $26-28$.

36. Mudford, B.; Stegemeier, D. Analyzing the Sensitivity of Production Sharing Contract Terms Using Simulation; SPE Hydrocarbon Economics and Evaluation Symposium: Dallas, TX, USA, 2003.

37. Bindemann, K. Production-Sharing Agreements: An Economic Analysis; Oxford Institute for Energy Studies: Oxford, UK, 1999.

38. Vasil'eva, A.G. Primenenie Soglashenij o Razdele Produkcii Mestorozhdenij Nefti i Gaza: Zarubezhnyj Opyt. Ekonomich. Nauki 2009, 60, 398-401.

39. Ogunleye, T.A. A Legal Analysis of Production Sharing Contract Arrangements in the Nigerian. Pet. Ind. J. Energy Technol. Policy 2015, 5, 8 .

40. Laughlin, R. Principals and Higher Principals: Accounting for Accountability in the Caring professions. In Accountability: Power, Ethos, and the Technologies of Managing; International Thomson Business Press: London, UK, 1996; pp. $225-244$.

41. Stewart, J. The Role of Information in Public Accountability. In Issues in Public Sector Accounting; Hopwood, A., Tomkins, C., Eds.; Philip Allen: Oxford, UK, 1984. 
42. Likosky, M. Contracting and Regulatory Issues in the Oil and Gas and Metallic Mineral Industries. J. Transnatl. Corp. 2009, 18, 1-42. [CrossRef]

43. Jenik, R. The ABCs of Petroleum Contracts: License-Concession Agreement, Joint Ventures, and Production-sharing Agreement. In Covering Oil: A Reporter's Guide to Energy and Development; Open Society Institute: New York, NY, USA, 2005.

44. Oon, K.C. The Politics of Oil in Indonesia: Foreign Company_Host Government Relations; Cambridge University Press: Cambridge, UK, 1986.

45. Briston, R.J. Accounting Standards and Host Country Control of Multinationals. Br. Account. Rev. 1984, 16, 12-26.

46. Dasgupta, P.S.; Heal, G.M. Economic Theory and Exhaustible Resources; Cambridge University Press: Cambridge, UK, 1979.

47. Babusiaux, D. Oil and Gas Exploration and Production Reserves, Costs, Contracts; Editions Technip: Paris, France, 2004.

48. Sergeev, I.B.; Lapochkina, L.V. Sustainable development: Theoretical and methodological approaches. J. Min. Inst. 2009, 184, 264.

49. Ghandi, A.; Lin, C.Y. Is Resource Nationalism on the Rise? Evidence from Service Contracts in Eight Countries First Quarter; International Association for Energy Economics: Cleveland, OH, USA, 2015; pp. 35-37.

50. Smith, E. International Petroleum Transaction, 2nd ed.; Rocky Moutain Mineral Law Foundation: Westminster, CO, USA, 2004; p. 448.

51. Bill of Law 5938/09-E.M.I n.00038 Article 14. 31/08/09. Available online: https://www.duo.uio.no/bitstream/handle/10852/ 22787 / ThesisFinal.pdf?sequence=1 (accessed on 15 May 2021).

52. Paliashvili, I. The Concept of Production Sharing, Seminar on Legislation on Product Sharing Agreement. Available online: http:/ / www.rulg.com/documents/The_Concept_of_Production_Sharing.htm (accessed on 15 July 2021).

53. República de Angola; Lei das Actividades Petrolíferas no 10/2004. Available online: https://www.sonangol.co.ao/Style\%20Lib rary/pt-pt/Pdf/licitacoes/law_petroleumTaxation_pt.pdf (accessed on 17 July 2021).

54. Handbook of Energy and Economic statistics of Indonesia; Directorate General of Oil and Gas: Ministry of Energy and Mineral Resources: Jakarta, Indonesia. 2013. Available online: https://www.esdm.go.id/assets/media/content/content-handbook-of-en ergy-economic-statistics-of-indonesia-2013-997ndnz.pdf (accessed on 15 July 2021).

55. Barrows, G. Production Sharing in Indonesia, 1966 to 1993: Evolution and Trends; Institute for International Research: Houston, TX, USA, 1993.

56. Sihotang, P. A longitudinal analysis of the indonesian production sharing contracts (PSC): The question of economic accountability. J. Win. 2003, 4, 94-111. [CrossRef]

57. PWC. Oil and Gas in Indonesia-Investment and Taxation Guide, 10th ed.; PWC: Londong, UK, 2019. Available online: https:/ / www.pw c.com/id/en/pwc-publications/industries-publications/energy--utilities---mining-publications/oil-gas-guide-2019.html (accessed on 15 May 2021).

58. Sihotang, P.; Russell, A. New Oil and Gas Law: Threat to Government? The Jakarta Post 29 October 2001.

59. Lytaev, A.V.; Tokarev, A.N. Usloviya Soglashenij o Razdele Produkcii Neftedobychi; Novosibirskij Gosudarstvennyj Universitet: Novosibirsk, Russia, 2011.

60. Pandey, A. Production Sharing Contracts in Indian Oil \& Gas Sector; Indian Institute of Management Ahmedabad: Ahmedabad, India, 2014.

61. Darus, M. Constitutionality in Production Sharing Contracts: Legal Policy On Petroleum And Natural Gas. Prophet. Law Rev. 2020, 2, 76-96.

62. Mikesell, R.F. Foreign Investment in the Petroleum and Mineral Industries: Case Studies of Investor-Host Country Relations; Johns Hopkins Press for Resources for the Future: Baltimore, MD, USA, 1971; p. 449.

63. Silvana, T. Fiscal Systems for Hydrocarbons; World Bank: Washington, DC, USA, 2007.

64. Bank, W. Indonesia: Oil and Gas Sector Study Report; World Bank: Washington, DC, USA, 2000.

65. Nevskaya, M.; Cherepovitsyn, A.E. Justification of an approach to an economic assessment of projects development of technogenic mineral objects. IOP Conf. Ser. Earth Environ. Sci. 2019, 302, 012049. [CrossRef]

66. Ponomarenko, T.V.; Tarasova, E.A. Luchshie praktiki upravleniya znaniyami v neftegazovyh kompaniyah. St. Peterburg Politekh. Univ. 2016, 2, 201-205.

67. Cherepovitsyn, A.E.; Ilinova, A.; Evseeva, O. Stakeholders management of carbon sequestration project in the state-BusinessSociety system. J. Min. Inst. 2019, 240, 731. [CrossRef]

68. Nikolaichuk, L.A.; Filatova, I.; Zakaev, D. Public-Private Partnership as a Tool of Sustainable Development in the Oil-Refining Sector: Russian Case. Sustainability 2021, 13, 5153.

69. Molchanov, K.; Romasheva, N. Conceptual approaches for building a balanced portfolio of projects in oil and gas companies in exploration and production sector. E3S Web Conf. 2019, 140, 03004. [CrossRef]

70. Nevskaya, M.A.; Seleznev, S.G.; Masloboev, V.A.; Klyuchnikova, E.M.; Makarov, D.V. Environmental and business challenges presented by mining and mineral processingwaste in the Russian. Minerals 2019, 7, 445. [CrossRef]

71. Katysheva, E.; Tsvetkova, A. Economic and institutional problems of the Russian oil and gas complex digital transformation. In Proceedings of the International Multidisciplinary Scientific GeoConference Surveying Geology and Mining Ecology Management, Albena, Bulgaria, 30 June-6 July 2019; STEF92 Technology Ltd.: Sofia, Bulgaria, 2019; Volume 19, pp. $203-208$. 